\title{
LUTHER SE LEER VAN DIE REGVERDIGING DEUR DIE GELOOF ALLEEN
}

Prof. L. F. Schulze

\section{PROLOOG}

In verskillende uitsprake wat Luther in later jare in sy "Tafelgesprekke" maak, beskryf hy hoe sy hele gang na die Reformasie gedra word deur die nuwe insig in die geregtigheid van God. In 'n sekere sin het die hele reformasie dus op hierdie begrip geskarnier. ${ }^{1}$

Die nuwe insig wat Luther in die betekenis en draagwydte van die uitdrukking 'geregtigheid van God' gekry het, was nie slegs 'n blote eksegetiese insig nie: dit was 'n nuwe eksegetiese insig wat teen die grein van 'n eeue-oue dogmatiese tradisie ingegaan het. Die ou tradisie word duidelik negatief afgegrens teenoor die nuwe insig in sy verklaring van Rom. 1:17: "En hier mag mens weer onder die 'geregtigheid van God' nie daardie geregtigheid verstaan waardeur $\mathrm{Hy}$ in Homself regverdig is nie, maar waardeur ons uit Hom geregverdig word. Dit geskied deur die geloof in die evangelie". ${ }^{2}$

Hierdie tradisionele dogmatiese opvatting was ook 'n oorsaak van Luther se aanvegting en verwyfeling. Dit blyk uit een van sy Tafelgesprekke waarin hy vermeld hoe hy aanvanklik geskrik het en vyandig was teenoor die woorde wat hy in die Psalms gelees en gesing het: "Bevry my in u geregtigheid" (Ps. 31:2, 71:2). Die geregtigheid van God was tog immers sy gestrenge oordeel wat vir hom die ewige verlorenheid sou beteken. Hy sou eerder 'barmhartigheid' wou lees. Maar toe hy die saak waaroor dit in die geregtigheid van God gaan, verstaan het, het hy die grammatika verstaan en het die psalms vir hom smaak gekry. ${ }^{3}$

In 'n sekere sin het die hele Reformasie om die regte verstaan van die 'geregtigheid van God' gewentel. Derhalwe is dit seker nie onvanpas om by wyse van 'n momentopname die aandag toe te spits op Luther se nuwe insig in God se geregtigheid soos dit in sy verklaring van Rom. $1: 17$ na vore kom nie. Dit gaan hier om 'n momentopname: nie om die hoe nie maar om die dat; nie om die wanneer nie maar om die wat. So word die skare Lutherinterpreteerders in stilte verby gegaan en die meester self aan die woord gestel.

Om hierdie insig van Luther egter in sy frisse krag en groot draagwydte te begryp moet dit teen die agtergrond van die laat Middeleeue in relief gebring word. Dit was immers vanuit die donker agtergrond van die skolastiese tradisie dat Luther na die lig van die evangelie beweeg het.

\section{AGTERGROND}

Petrus Lombardus was die eerste groot dogmatikus van die latere Middeleeue. Hy was die man wat 'n oorwegende eksegetiese oorlewering in 'n sisteem omgebou het. In hierdie proses het hy ook die skolastiese geregtigheidsbegrip geyk.

Natuurlik was die werk van Augustinus aan hom bekend. Trouens, sy Sententiae wemel van aanhalings uit Augustinus. So haal hy ook uitdruklik Augustinus se omskrywing van die geregtigheid 
van God uit sy De spiritu et litteras aan: "So ook word die geregtigheid van God beskou nie alleen as daardie geregtigheid waardeur $\mathrm{Hy}$ self regverdig is nie, maar ook daardie geregtigheid wat $\mathrm{Hy}$ aan die mens gee as Hy die goddelose regverdig"." Die merkwaardige is egter dat hierdie fundamentele insig van Augustinus nêrens in Lombardus se sistematisering 'n rol speel nie. Daarom vind ons in geen latere Sententia-kommentaar meer enige verwysings na Augustinus nie. Wanneer Lombardus dan die geregtigheid van God ter sprake bring, $\mathrm{nl}$. by die beskouing oor die eindgerig," kom dit veral in die tradisionele probleemstelling na vore: wat is die verhouding van geregtigheid en barmhartigheid ?' Met 'n beroep op o.a. twee uitsprake in Cassiodorus se Psalmkommentaar ${ }^{*}$ stel Lombardus dat die onderskeiding van geregtigheid en barmhartigheid hoegenaamd nie die eenheid van God se wese ophef nie maar slegs twee verskillende maniere is waarop God Hom kenbaar maak. Die openbaring van sy geregtigheid beteken in ieder geval vergelding in die vorm van loon of sitraf.

Die werke van geregtigheid is immers daardie werke wat aantoon dat God Regter en "gelyke Verdeler" is. " Nêrens in Lombardus se uiteensetting word 'geregtigheid' anders as 'vergeldende geregtigheid' gesien nie. Augustinus het final uit die gesigsveld verdwyn, want sy opvatting van geregtigheid kon hoegenaamd nie meer as ' $n$ tweede faset langs die streng gedefinieerde Vergeldingsgeregtigheid gestel word nie.

Met die bydrae van Lombardus was die kiem geplant waaruit 'n filosofiese geregtigheidsopvatting sou groei. Hiervoor is teruggegryp op Aristoteles, maar ook Anselmus het 'n eie bydrae gelewer: die geregtigheid en barmhartigheid van God is versoen in die beskouing dat albei strook met die goedheid van die goddelike Wese. ${ }^{10}$ In die werke van Biel, waaruit Luther sy kennis van die Skolastiek opgedoen het en wat hy byna uit sy kop geken het, word die sintese van geregtigheid en barmhartigheid nie volgehou nie: geregtigheid word weer geskei van barmhartigheid. Maar die wesenlike karakter van die begrip bly behoue soos dit in die skolastiek sy beslag gekry het. Dit is ingebed in die Aristoteliese deugdeleer ${ }^{11}$ en is 'n eienskap van God op grond waarvan hy elkeen vergeld volgens sy verdienste. Tog lê die aksent op die straffende aard van die geregtigheid, want God moet elke sonde met 'n daad van sy geregtigheid beantwoord." Biel behou egter ook die gedagte van die "paslikheid" van die goddelike goedheid wat van Anselmus afkomstig is. Dit is egter nou nie meer die hoëre begrip wat 'n 'geregtigheid' en 'barmhartigheid' saamvat nie maar dit rem en versag die straffende geregtigheid. ${ }^{13}$ Met behoud van hierdie gedagte van Anselmus word dit ook moontlik om, nes hy gedoen het, die barmhartigheid uit die geregtigheid af te lei. Maar dit geld dan net vir die geregtigheid in 'oneintlike' sin. Daarenteen is die geregtigheid in 'eintlike sin' altyd vergeldende geregtigheid, kongruent aan die verdienste of skuld van die mens. ${ }^{14}$ Vanselfsprekend moet die mens dan 'n vrye wil hê; anders sou hy nie sy regverdige beloning of straf kan ontvang nie. ${ }^{15}$

Só het die skolastiese erfenis gelyk wat Luther geabsorbeer het. Dit was die wrange medisyne wat Luther moes drink - wrang om- 
dat dit nie veel verbeelding kos om in te sien dat dit 'n kunsmatige en onmoontlike mengsel was nie.

Dit spreek boekdele vir die erns, skerpsinnigheid en opregtheid van Luther se denke dat hy hom konsekwent aan die duidelike geformuleerde 'eintlike' spraakgebruik gehou het. Hy kon trouens nie op die wankelende bodem van 'n 'oneintlike' geregtigheid sy sielerus gaan soek nie - en juis dáarom het dit vir hom gegaan. Daarom hou hy hom aan dit wat duidelik en gegrond was: die ondubbelsinnige onderskeiding van 'geregtigheid' en 'barmhartigheid' en die haglike toedrag van sake dat God se barmhartigheid deur sy geregtigheid begrens word. ${ }^{10}$

In die Rooms-Katolieke praktyk van goeie werke, van beloning en vergelding het hy ten regte ' $n$ bevestiging van hierdie skolastiese geregtigheidsbegrip gesien. Die benoude effek van die oordrag van in filosofies gekleurde en algemeen menslike geregtigheidsvisie op die lewende God van die Skrifte het hy in sy aanvegtinge aan die eie lyf ervaar. So dwing sy intense soeke na 'n genadige God hom om te gaan worstel met die betekenis van die uitdrukking 'geregtigheid van God', totdat hy eindelik weer die Bybelse sin daarvan sou terugvind.

\section{DIE NUWE INSIG}

"Want die geregtigheid van God is daarin geopenbaar" ... (Rom. 1:17a). ${ }^{17}$ In die Scholae merk Luther op: "Die geregtigheid van God waarkragtens iemand sodanige heil waardig is waardeur hulle alleen voor God regverdig is . . . is daarin geopenbaar. Want voorheen, toe dit verborge was, is gemeen dat dit op die eie werke gegrond is. Maar nou word dit 'geopenbaar' dat niemand regverdig is nie behalwe hy wat glo". ${ }^{18}$ In die Glossa brei Luther verder hierop uit en sê:

"In menslike leerstellinge word die geregtigheid van die mense geopenbaar en geleer, naamlik wie regverdig is en op watter manier iemand in sy eie ö̈ en voor die mense regverdig is en regverdig word. Maar alleen in die evangelie word die geregtigheid van God geopenbaar (dit wil sê, wie regverdig is en hoe hy voor God regverdig is en word) deur die geloof alleen, waarmee die Woord van God geglo word. Soos in die slot van Markus: 'Hy wat sal glo en gedoop sal wees, sal gered word. Wie inderdaad nie sal glo nie, sal veroordeel word'. Want die geregtigheid van God is die oorsaak van die heil. ${ }^{19}$ En hier mag mens weer onder die 'geregtigheid van God' nie daardie geregtigheid verstaan waardeur $\mathrm{Hy}$ in Homself regverdig is nie, maar waardeur ons uit Hom geregverdig word. Dit geskied deur die geloof in die evangelie. (Daarom sê die salige Augustinus in De spiritu et littera hfst. 11: 'Daarom word dit geregtigheid van God genoem omdat Hy deur die mededeling daarvan regverdiges maak. Net soos die heil van God dit is waardeur Hy saliges maak'.20 En dieselfde sê hy in hoofstuk 9 van daardie boek)".

"En dit word gesê om dit te onderskei van die geregtigheid van die mense wat uit die werke kom. Soos Aristoteles in die derde boek van sy Etiek dit duidelik stel. Volgens hom volg die geregtigheid die 
dade en word deur hulle bewerk. Maar volgens God gaan die geregtigheid aan die werke vooraf en ontstaan hulle daaruit . ..".

"Regverdige werke van mense wat nog nie regverdig is nie, is soos werke van 'n priester en 'n biskop wat 'n mens verrig terwyl hy self nog nie 'n priester is nie - dit is dwaas en belaglik en 'n ewebeeld van harlekynekuns".

Wanneer ons hierdie woorde van Luther teen die agtergrond van die skolastiese tradisie sien, spreek hulle eintlik vir hulleself. Tog is dit nodig om hieroor nog enkele opmerkings te makk.

1. Die onderskeiding van goddelike en menslike geregtigheid was vir die Reformasie van groot belang. Ook Calvyn maak hierdie onderskeiding. ${ }^{21}$ Die menslike geregtigheid bestaan daarin dat ons voor die mense regverdig is. Dit bepaal die verhouding van mense met mekaar. Hierdie opvatting van geregtigheid as 'n norm wat menslike verhoudinge bepaal, kom van die Grieke af. Vir Aristoteles was geregtigheid een van die deugde wat nie net op jouself betrekking gehad het nie maar veral jou verhouding tot die medemens bepaal het.

Nou kom Luther en sê dat ons God se geregtigheid nie in terme van menslike geregtigheid moet verstaan nie. By die goddelike geregtigheid gaan dit nie om 'n geregtigheid wat voor die mense kan bestaan en wat bloot menslike verhoudinge bepaal nie, maar dit gaan juis om daardie geregtigheid wat voor God kan bestaan. Geregtigheid voor God en voor die mense is hier eintlik 'n teëstelling. Luther het later in sy bemoeienis met die owerhede (veral tydens die boere-opstand en daarna) hom versigtiger uitgedruk. Ons moet in ieder geval hierdie skerp afgrensing nie sien as 'n dualisme tussen God se wêreld of natuur en genade nie. Luther neem hier die werklikheid van die sonde in ag waardeur 'n gehoorsame en aanvaarbare landburger tog voor God nog 'n skuldige sondaar is.

2. By die verstaan van 'geregtigheid' maak Luther ook 'n teëstelling. Hy sê uitdruklik dat ons die uitdrukking 'geregtigheid van God' nie moet verstaan as 'n eienskap van God "waardeur Hy in Homself regverdig is nie", maar as 'n gawe van God "waardeur Hy ons regverdig maak". Ook hierdie teëstelling moet ons nie mislei nie. Dit beteken nie dat hy ontken het dat God self regverdig is nie. Dit beteken wel dat ons Rom. 1:17 só moet verstaan dat dit nie die eienskap van God is wat in die evangelie geopenbaar word nie maar juis die geskenkte geregtigheid wat deur die geloof in die evangelie ons deel word en maak dat ons voor God se aangesig reg kan staan. Vir Luther was God sonder twyfel self regverdig. Daarom deel God in die regverdigmaking Homself aan ons mee en kry ons as't ware deel aan sy bestaan. Daarom kan Luther hier in navolging van Augustinus selfs die gewaagde term 'vergoddelik" gebruik.22

Hoe die lyne vanaf die 'vreemde woorde' van Ps. 31:2 (resp. $71: 2$ ) — "red my deur U geregtigheid" - na Rom. 1:17 loop, is moeilik om te ontrafel. Daaroor stry die geleerde mense tot op hede. $^{23}$ Moontlik het die gevreesde woorde uit Ps. $31: 2$ hom aanvanklik aan die worstel gesit - 'n eksegetiese worsteling met die begrip 'geregtigheid' wat voortduur totdat die lig vir hom in die 
uitleg van Romeine opgegaan het. In hierdie worsteling moet ons aanneem dat daar 'n voortdurende eksegetiese wisselwerking tussen die verskillende Bybelse uitsprake oor die geregtigheid was. Luther suggereer dit self in sy Operationes in Psalmos van 1519 wanneer hy by Ps. $5: 9$ weer oor die geregtigheid van God gaan praat. Dan word dit weer geformuleer soos hy vier jaar tevore in Rom. 1:7 gedoen het. Hierdie siening bevestig hy met Rom. $3: 21 ; 10: 3$; Ps. $31: 2$ en met Augustinus se De spiritu et littera. ${ }^{24}$ Wanneer Luther 26 jaar later in die voorwoord van sy Latynse werke weer eens op die beslissende gang van sy lewe terugkyk, kom al die elemente wat reeds in sy Psalmkommentaar van 1519 genoem is, weer terug.

3. Uit die aanhaling van Luther kom die gedagte dat die geregtigheid ons toegereken word, beslis nie duidelik na vore nie. Dit blyk eerder dat hy hier aan 'n letterlike regverdigmaking van die mens gedink het. Die vergelyking van die goeie werke van iemand wat nog nie regverdig is nie met die dienswerk van 'n priester wat nog nie bevestig en geheilig is nie, suggereer hierdie betekenis baie duidelik. Wanneer ons dan ' $n$ bietjie verder in Luther se werke gaan lees, word dit duidelik dat hy die regverdiging in die eerste plek as 'n regverdigmaking en 'n vernuwing van die mens gesien het. ${ }^{25}$ Ons kom dit telkens teë: God maak ons regverdig; Hy skenk ons die geregtigheid, ${ }^{26}$ wat dieselfde is as die genade wat Hy skenk.

Laat ons hier egter 'n derde keer vir 'n misverstand op ons hoede wees. Ons kan maklik dink: Ha! hier het Luther nog halfpad in die Roomse leer bly vassteek. Rome los tog immers die regverdigmaking in die heiligmaking op en leer dat die regverdigmaking 'n proses is waarin die mens daadwerklik al meer in sy lewe regverdig word. Hierdie leer is bowendien deur die Konsilie van Trente bekragtig!

'n Mens sou in Luther se sakramentsleer nog reste van die Roomse suurdeeg kan vind, maar nie hier nie. Eerstens leer die Skrif tog ook dat ons deel kry aan die geregtigheid en heiligheid van Christus. Tweedens moet ons nie hier dink aan 'n nuwe kwaliteit of habitus wat in die mens ingeplant word nie, want Luther sien die regverdigmaking as 'n daad van God se barmhartigheid. ${ }^{27}$ Derdens, Luther kom as eksegeet tot hierdie insig en vind sy siening deur Augustinus bevestig. Luther se uitsprake oor die geregtigheid herinner soms tot die klank van die woorde aan Augustinus. ${ }^{28}$ Vierdens ken Luther inderdaad óók die gedagte van toerekening van Christus se geregtigheid. Daarom kan hy so dikwels die uitdrukkings iustum efficere en iustum reputare afwissel. Die mens is as sondaar in die proses van die regverdiging begrepe. Terselfdertyd is hy egter ook regverdig omdat die geregtigheid wat Christus in hom werk, hom toegereken word. "So is ons dus in onsself sondaars en tog deur God regverdig deur die geloof gereken". ${ }^{29}$

Hoewel Luther later groter klem op die toerekening van die genoegdoening van Christus gelê het, het hierdie tweeledige karakter van die geregtigheid van God by hom behoue gebly. Geregtigheid is toerekening én genesing. Die gelowige word opgeneem in die één groot oorwinning van Christus oor Satan, hel en dood. Daarom kan 
die forensiese en effektiewe sy van die regverdigmaking net so min geskei word as wat die Persoon en werk van Christus geskei kan word.

\section{SAMEVATTING}

Ons sien hierdie Augustynermonnik wat in sy aanvegting eerlik worstel $^{30}$ om die Skrif te verstaan. Stap vir stap word hierdie kosbare pêrel, nl. die geregtigheid van God, uit sy filosofiese, algemene menslike en gemeenregtelike omhulsels losgewikkel. Dan meteens lê die pêrel in al sy kleureprag voor hom. In sy omhulsel was dit skrikwekkend; die strenge geregtigheid wat aan God eie is waarkragtens Hy aan elkeen uitdeel wat hy verdien het. Dit het Luther gevrees want dit kan vir die sondaarmens alleen die verdoemenis bring. Maar nou lê die pêrel in al sy skoonheid voor hom: dit is die geregtigheid wat uit God voorkom en wat Hy in sy genade aan ons meedeel. As Luther dit sien, gaan die poorte van die paradys vir hom oop.

Grammatikaal gesien gaan Luther se nuwe insig eintlik om 'n onbenulligheid, naamlik om die vraag hoe ons die genitief, die besitlike vorm 'van God' moet verstaan. Dui dit 'n eienskap aan wat God besit, of dui dit 'n geskenk aan waarvan Hy die Bron is? Die eerste moontlikheid het die Skolastiek geleer; die tweede moontlikheid het Luther weer ontdek. En dan gaan blaai hy vreugdevol deur die Bybel om die genitiewe te lees: die krag van God is die krag waardeur Hy ons sterk maak, die wysheid van God is dit waardeur Hy ons wys maak, die liefde van God is die liefde waarmee Hy ons bemin en wat $\mathrm{Hy}$ in ons uitstort. Hy sien selfs sy nuwe ontdekking bevestig deur die Hebreeuse status constructus! En hy gaan soek na taalkundige parallelle: die geregtigheid van God is gelyk aan die genade van God, aan die werk van God en aan die weg van God waarop Hy ons plaas. ${ }^{31}$

'n Taalkundige kleinigheid! Maar watter implikasies het dit nie; hoeveel kleure word nie in hierdie onthulde pêrel weerkaats nie! Luther weet dat hierdie taalkundigheid hom weer by die hart van die evangelie gebring het, want hy sê: "Die artikel van die regverdigmaking moet dus, soos ek dikwels herinner het, noukeurig geleer word. Want daarin is al die ander artikels van ons geloof saamgevat ... Aangesien ons dus leer dat die mense deur Christus geregverdig word en dat Christus die oorwinnaar van sonde, dood en ewige vloek is, getuig ons terselfdertyd dat Hy na sy Wese God is. ${ }^{32}$

Hierdie pêrel wat Luther weer in die lig gestel het, weerkaats soveel kleure: die genade van God, die regverdigverklaring én regverdigmaking (heiliging, ${ }^{33}$ die godheid van Christus en sy oorwinning oor dood en hel - in kort: dit weerkaats die veelkleurigheid van die één groot verlossingswerk van God waarin die perfectum tegelyk ook praesens is. ${ }^{34}$

Daarom kon Luther jubel: "Wo Vergebung der Sünden ist, da ist Leben und Seligkeit".

\section{EPILOOG}

Hierdie vreugdevolle insig van Luther was nie vir vele beskore nie. Of wil die mens dit eintlik nie sien en aanvaar nie? Lê dit meer 
in die aard van die mens om te dink as om te aanvaar, om hierdie pêrel nie dankbaar aan te gryp nie maar weer in sy eie gedagtespinsels toe te wikkel? Dis 'n moeilike vraag om te beantwoord. Die feit is dat die Protestantse mens, net soos sy Rooms-Katolieke medemens, gaan dink het, gaan rasionaliseer het. Daarmee het hy agter Luther verby weer in die troebel waters van die Skolastiek teruggeval nie skielik nie en ook nie so diep dat hy heeltemal verdrink nie. Nee dit gaan geleidelik, met talle subtiele aksentverlegginge en rasionalistiese onderskeidings, terwyl hy die kern van die sola gratia tog styf in sy hand hou. Maar dit is nie meer die pêrel van Luther nie. ${ }^{35}$

In wese word die geregtigheid van God as geskenk in sy tweeeenheid van regverdigverklaring en regverdigmaking stukkend gebreek. Regverdiging word 'n suiwere toerekening van die 'vreemde geregtigheid' van Christus wat ek altyd weer moet glo maar wat eintlik in my lewe nie kant of wal raak nie. Hierby sluit die eksistensieteoloë van ons dag dankbaar aan. En die regverdigmaking dan? Dit word 'n aparte stap op die heilsweg. So onderskei die verstand - onskuldig genoeg - maar daarmee word die één oorwinningswerk van Christus ten slotte helaas ook chronologies geskei.

Wanneer die geregtigheid in sy twee-eenheid gebreek word, lê die gevaar van buiteverdeling lewensgroot en loer. Is die toerekening van die geregtigheid nie tog God se werk as die heiligmaking die mens se werk nie? Langs hierdie weg word die heiligmaking ten slotte tog weer die voorwaarde vir die regverdiging, die bewys dat jy 'n Christen is, 'n medewerker in die realisering van die heil. Daarmee is ons oor die boeg van die Piëtisme en Metodisme binne-in ons eie tyd met al sy Christelike variasies, van geesdrywery tot revolusiestokery, waar die kerk die groot uitdeler van menslike geregtigheid word. Maar daarmee is ons terug by die Skolastiek, want wie 'menslike medewerking' sê, veronderstel nie net die vryheid van die wil nie $^{36}$ maar ook die vergeldende geregtigheid van God Daarmee is die sirkel voltooi en is ons weer waar ons begin het.

Dit is tyd dat ons weer die grammatica van die Skrif gaan leer.

(Gelewer by die Luther-kongres van die Kerkhistoriese Genootskap van die NH Kerk van Afrika).

\section{VERWYSINGS}

1. Max Geiger en Ferdinand Hahn: Kerkgeskiedenisseminaar, Universiteit van Basel, April-Junie 1967 (ongepubliseerde aantekeninge).

2. "Et hic iterum 'Iustitia Dei' non ea debt accipi, qua ipse Iustus est in seipso, sed qua nos expso lustificomur, quad fic per fidem euangelii" (WA $56: 172$, my kursivering).

3. 5247: "Ius ¿itia Dei. Da ich erstlich im Psalmen lass und sang: In iustitia twa libera me! da erschrack ich alle mal und war den Worten feindt: Iustitia Dei, indicium Dei, opus Dei, denn ich wusst nichts anderes, iustitia Dei hies sein gestreng Gericht. Nuhn solt er mich noch seim 
gestrengen Gericht erretten? So wer ich ewig verloren! Aber misericordia Dei, adiutorium Dei, die Wortt hett ich lieber. Gott lob, da ich die res verstundende und wiste, das iustitia Dei hiess iustitia, qua nos inustificate per donatam iustitiam in Christo Ihesu, da verstunde ich die grammatica, und schmeckt mir erst die Psalter" (WATi 5:26). Vgl. hieroor ook H. Bornkamm, Luther. Gestalt und Wirkungen, Gütersloh, 1975 , p. 117.

4. Die teks van hierdie werk van Augustinus is opgeneem in MPL $44: 201$ 246 en CSEL $60,1: 155-229$.

5. "Sic etiam dicitur iustitia dei non solum illa, qua ipse iustus est, sed etiam illa, quam dat homini, cum iustificat impium" Sitaat by Bornkam a.w., p. 103. Sy verwysing na Sent. 3.35 .3 by hierdie sitaat is foutief. Dáár haal Lombardus nie uit Augustinus aan nie.

6. Sent. 4.46.1 e v. (MPL $192: 951$ ).

7. Sent. 4.46.3 (MPL $192: 952-953$ ).

8. Ps. $50: 15$ en Ps. $100: 1$.

9. ". . quibus ostenditur judex et aequus distributor" (MPL $192: 952$ ).

10. In sy Proslogion (hfst. 10) spreek Anselmus God soos volg aan: "Cum punis malos, iustum est, quia illorum meritis convenit; cum vero parcis malis, iustum est, non quia illorum meritis, sed quia bonitati tuae condecens est." Hierdie gedagte van die conde centia bonita is divine lei Anselmus af uit sy algemene geregtigheidsbegrip ("Iustitia est rectitudo voluntatis, quae rectitudo proper se servatur" - Dial de vertitate 12) én uit die feit dat God summum bonum is. Sitate by Bornkamm, a.w. p. 105. Deel 158 van MPL, waarin die meeste van Anselmus se werke opgeneem is, was ongelukkig nie tot my beskikking nie.

11. Geregtigheid is virus dirigens appetitum, ut sebene haeat in ordine ad alterum (Collectorium 3.34c).

12. Collect. 2.36c en D.

13. In Biel se Cellectorium ontbreek sy kommentaar op die laaste 29 Distinctions van Lombardus - ook dus dié op dist.. 46 van boek 4 , wat juis vir ons van wesenlike belang is. Daar is egter 'n byvoegsel by die werk waarin Biel se leerling, W. Steinbach, die werk van sy meester afgerond het. Daarin vind ons, juis by dis kommentaar op Sent. 4.46 - baie insiggewend omskrywing van ira divina, iustitia divina en misericordia divina (Teks by Bornkamm, a.wh, p. 114, n. 84).

14. Biel-Steinbach: In Sent. 4.46 ad art. 3: "Inustitia est decentia voluntatis divinae secundum merita vel demerita."

15. Ibid.: "Et sic iustitia solum reperitur" vel effectus iustitiae circa rationalem creaturam habentem liberum arbitrium" (Vgl. Bornkamm, a.w.p. 114, n. 86).

16. Ibid. ad art. 2F: "Deus non semper miseretur, quia non semper aufert miserias voluntate consequente, sed secundum ordinem divinae iutsitiae et nonnumquam pro hominis merito vel demerito".

17. WA $56: 10,171-173$; M. Luther: Vorlesing über den Römerbrief 1515-1516 (vert. E. Ellwein), München, 1955, pp. 23-25.

18. "Iusticia qua tali salute dignus est enim dei qua sola iusti sunt coram Deo in ea revelatur quia prius abscondita putabatur ex operibus propiis constare. Sed nunc 'revelatur' quod nullus est Iustus, nisi qui credit" (WA $56: 10$ ).

19. "Iusttia enim Deiestcausa salutis" (WA $56: 172$ ). By Calvyn kan 'n mens 
in sy Romeinekommentaar op $1: 17$ presies dieselfde gedagte: "Haec autem iustitia, quae fundamenium est salutis, revelatur in evangelio" (OC $49: 20$ ).

20. 'Ideo Iustitia Dei dicitur, quod impertiendo eam Iustos facit. Sicut Domini est salus, qua saluos facit' (ibid).

21. Comm in epist. Pauli ad Rom. 1:17: "Iustitiam Deiaccipie, quae apud Dei tribunal approbetur: quemadmodum contra hominum iustitiam vocare solet, quae hominum opinione habetur et censetur iustitia, licet fumus iantum sit' (OC $49: 20$ ).

22. 'Vergoddelik' beteken by Augustinus niks anders as 'heilig' nie. Vgl. o.a. Enarr. in Ps. $49: 2$ : "Manifestum est ergo, quia homines dixit doos, ex gratia sua deificatos, non de substantia sua natos. Ille enim iustificate, qui per sementipsum non ex alio iustus est, et ille deificat, qui per seipsum non alterius participatione Deus est Qui autem iustificat, ipse deificat, quia iustificando, filios Dei facit" (CCSL $38: 575-576$ ).

23. Dink maar aan die werke van Vogelsang, Holl, Hirsch, Bizer, om maar enkeles te noem. Vir 'n resente oorsig oor verskillende Lutherinterpretasies en Luther se invloed op die tyd na hom, kyk G. Ebeling: "Der kontroverse Grund der Freiheit. Zum Gegensatz von Lutherenthusiasmus und Lu'herfremdheit in der Neuzeit", in: Luther in der Neuzeit, Gütersloh, 1983, pp 9-31.

24. WA $5: 144$.

25. Hierop het van Rhijn en de $\mathrm{Ru}$ tereg gewys. Vgl. de Ru: De rechtvaardiging bij Augustinus, Wageningen, 1966, p. 83 e.v.

26. Vgl. bv. WA $3: 199,200,286$.

27. Luther, Dictata super Psalterium, Scholae Ps. 4: "eius enim misericordia est mea iustitia" (WA $3: 43$ ).

28. Vgl. vir voorbeelde, du Ru, a.w., p. 84 e.v.

29. Scholae Rom. 4: 7: "Sic ergo in nobis summus preccatores et tamen reputante Deo iusti per fidem". En ook: "Numquid ergo perfecie iustus? Non, sed simul pecator et iustus: peccator re vera, sed iustus ex reputatione et promissione Dei certa, quod liberet ab illo, donec perfecte sanet. Ac per hoc sanus perfecte est in spe, in re autem peccator, sed initium habens iustitae, ut amplius quaerat semper, semper iniustum se sciens" (my kursivering). Die uitdrukking 'genees' gebruik Augustinus ook dikwels. Vir die teks kyk Johannes Ficker (red.) Anfänge reforma orische Bibelauslegung 1,2: 107-108; Ellwein, p. 171-172, WA 56:271-272. Vgl. ook vir die voortdurende poses, G. Ebeling: Luther. Einführung in sein Denken, Tübingen, 1964, veral p. 181 e.v.

30. Vgl. J. Alkinson, Martin Luther and the birth of Protestantism, Harmondsworth, 1968, p. 69 e.v.

31. Vgl. WA $5: 144$.

32. In ep. S. Pauli ad Cal. comm.: "Locus igitur Iustifications, ut saepe moneo, diligenter discendus est. In eo enim comprehenditur omnes alli fidei nostrae articuli . . Quane cum docemus homines per Christum iustifiari, Christum esse victorem peccati, mortis et aeternae maledictionis, teslificamur simul eum esse natura Deum" (WA 40,1:441).

33. P. Althaus, Die Ethik Martin Luthers, Gütersloh, 1965: "Die Rechtfertigung bestimmt die Ethik idem sie erstens das Vorzeichen des sittlichen Lebens und zweitens seine Quelle wird" (p.11).

34. WA 2: 146: "cum infirmi essemus secundum tempus, licet iam coram 
deo essemus in praedestinatione iusti, quia in praedestination dei omnia facta lam sunt in rebus adhuc, futura sunt".

35. Kyk vir hierdie ontwikkeling: $R$. Seeberg, Lehrbuch der Dogmengeschichte Leipzig, 1920, IV, p. 467 e.v.; Van Rhijn, a.w. p. 1-10; De Ru, a.w., p. 89 e.v.

36. Dat die synergisme en die leer van die wilsvryheid 'n vorm van rasionalisme is, het Harnack duidelik belig: "Der Ursprung des Pelagianismus ist . . . der consequent entwichelte christliche Rationalismus" (Lehrbuch der Dogmengeschichte, Tübingen, 1910, III, p. 171).

\section{AFKORTINGS VAN NAME VAN STANDAARDBRONNE}

CCSL - Corpus Christianorum series latina.

CSEL - Corpus scriptorum ecclesiasticorum latinorum

MPL - J. P. Migne: Patrologia latina.

OC - Opera Calvini.

WA - D. Martin Luthers Werke, Kritische Gesamtausgabe, Weimar.

WATi - Luther se Tischredon in die Weimarer Ausgabe. 